\title{
Fighting Back Against the Encroachment of Patriarchal Power on Female Domains in Wuthering Heights
}

\author{
Banu Akcesme \\ Faculty of Arts, Erciyes University, Erciyes Universitesi, Edebiyat Fakultesi, Melikgazi, 38039, Turkey \\ E-mail: banu_akcesme@hotmail.com
}

Received: 15-01-2017

Accepted: 03-04-2017

Published: 01-09-2017 doi:10.7575/aiac.ijalel.v.6n.5p.27
Advance Access Published: July 2017

URL: http://dx.doi.org/10.7575/aiac.ijalel.v.6n.5p.27

\begin{abstract}
Wuthering Heights can be read as a novel of warfare against women and women-associated spaces to be conquered to prove male superiority, authority and power. This paper aims to discuss how Emily Bronte challenged not only the established Victorian literary traditions but also the prevailing ideals of the Victorian society by subverting the hierarchically constructed power and gender relations with an emphasis on various strategies employed by Heathcliff and Edgar in the war they launch against nature, property and women to conquer, possess and control domestic households, external nature and female body. Their strategies include reductionism which includes the commodification and objectification of female body, separation of women from their female bond, family and female spaces, physical and emotional uprooting which causes the loss of independence, self-confidence and positive selfimage, masculinization of nature and home, brutalization through which the female characters are exposed to male violence and oppression and destruction of a sense of security, commitment and resistance. The female characters are disconnected not only from their domestic households and nature but also from female bonds. The sense of placelessness and homelessness along with the lack of female solidarity is aggravated by transforming home and the natural world into an imprisoning, dominating and tyrannical web for women. Bronte ends the novel with a hope that subjugation and subordination does not have to be the inevitable destiny for women who can fight back to restructure the existing power relations and reclaim their bodies and home along with nature turned against them.
\end{abstract}

Keywords: Wuthering Heights, Emily Bronte, Victorian Fiction, nature, liberation of women

\section{Wuthering Heights as a novel of Subversion}

Emily Bronte is one of the most controversial and daring novelists of the Victorian Era and her only novel Wuthering Heights (referred to as $\mathrm{WH}$ from now on) was received by harsh criticism, hostility and rejection. She wrote in a period which required the acknowledgement of social and gender propriety, decorum and class consciousness. The Victorian Society is marked by its persistence on conventionality, moderation, strict sexual morality, and parental authority and discipline. Although Victorians enjoyed the progress and advancement made possible by imperialism and capitalist industrialism, there were many challenges that disturbed the sense of stability and confidence in the Victorian Society. Cory maintains that during the late 1830 s and 1840 s "Britain was in a state of turmoil [...] as many of the social and political structures that constitute the capitalist, patriarchal state were threatened by various kinds of militance and social movements" (2) like Young Ireland Movement and Chartism. These two movements challenged the ruling middle and upper classes through "their calls for a more equitable distribution of socio-political power" (Cory 5). Emily Bronte in her transgressive and subversive novel reflects these challenges and calls into question the prevalent ideals of society by touching on the unspeakable, invisible and the untouchable of the Victorian society and literature. $W H$ deserves critical attention for creating a new discursive space to destabilize the established literary, social, cultural norms and conventions deeply rooted in the $19^{\text {th }}$ century and to manifest and expel the repressed in human psyche which threaten and disturb the Victorian society. This paper intends to systematize how Emily Bronte has achieved to problematize the Victorian dualism and essentialism by deconstructing the relations between the strictly maintained oppositional categories between man and woman, culture and nature, white and black, tame and wild, and high class and low class. Firstly, the emphasis is placed on the subversive aspect of the novel. Then the war that is carried out by Edgar, Heathcliff and Hindley will be explained to illustrate the encroachment of male power on the female body and female-associated spaces to exert superiority and control. Lastly, the resistance shown by the female characters to reclaim their body, home and nature will be discussed.

Although Charlotte Bronte in the preface to $W H$ describes her sister as "home-bred, country girl" who writes in "nunlike seclusion", what makes WH "exceptional" (Tytler 44), "unique" (Levy 158), an extraordinary novel is Emily Bronte's untraditional and nonconformist personality which challenges the ideals of femininity in the $19^{\text {th }}$ century as observed by her teacher Constantin Heger: "She should have been a man - a great navigator. Her powerful reason would have deduced new spheres of discovery from the knowledge of the old, and her strong, imperious will would never have been daunted by opposition or difficulty, never have given way but with life" (qtd. in Heywood 17). Although Emily 
Bronte is described as the mixture of two important pre-Victorian writers, Walter Scott who celebrates "the common sense, ordinariness of the lowlands and of the ideal of quiet domesticity" and presents the Highlands as "dangerous", "seductive", "threatening" and "doomed" and Mary Shelly who uses the mountains, the Alps and Gothic extremes in her novel Frankenstein (Levine 145), she is more interested in exploring the gender and gender-related issues within the framework of power relations which are never stable and fixed but in flux and thus constantly subject to deconstruction and reconstruction.

$W H$ is a controversial novel which has yielded to a great number of different categorizations and interpretations. "Unorthodox Victorian novel", "metaphysical romance", "romantic supernatural", "natural supernatural", "male wilderness novel" (Williams 104-105), the "fierce romance" (May 415), "amoral book", "anti-Christian novel", "bildungsroman", "mythological romance" (Piciucco 221) are just a few of the labels attached in an attempt to define $W H$ and identify its status in the canon. Because of the indeterminacy and complexity of the text which produces a multiplicity of meanings, it has also been recently embraced as a poststructuralist novel. This overwhelmingly sensational and ground-breaking novel has been studied from different perspectives including the feminist, Marxist, autobiographical and psychoanalytical. The difficulty of studying $W H$ results from the fact that $W H$ defies all strict categories and definitions. $W H$ is not only an attempt to liberate itself from the strict Victorian literary conventions and genres but also from gender, class and race-based stereotypes. Because of its impetus to go beyond the established boundaries, it has been found essentially disturbing and perverse.

Bronte and her novel $W H$ have not been appreciated fully with their merits in the hands of the sexually prejudiced 19th century male critics because of the prevalent sexual double standards (Ohmann 906-913) who wholeheartedly believed that women writers had no "originality, intellectual training, abstract intelligence, humor, self-control, knowledge of male character" (Showalter 90). The gender of the writer along with the speculations around her authorship has played a determining role in the way $W H$ has been received. The critics sought a way to resolve the inherent discordance by negotiating the unfeminine qualities of the novel and the sex of the writer. Because of the misattribution of the novel to a male writer for Bronte's use of male pen name Ellis Bell, the earlier reviews received a great amount of praise for its daring originality, boundary-transcending creativity and apparent masculine qualities. However, after her identity was unveiled, the shockingly unusual and unconventional plot along with unfeminine brutality and unwomanly coarseness brought disgrace and rejection since the novel was not reconciled with the established writing traditions set up for women writers.

Joanna Russ, in her book How to Suppress Women's Writing, explains denial and pollution of agency have been systematically employed by the male critics to discourage and hinder women's writing. Russ also states that false categorization is commonly used to underestimate the literary works produced by women writers, and women`s works are deliberately assigned to false categories: "the label regionalist, so often applied to women writers, indicates not only that the writer in question concentrates on a particular region, but also that the work is thereby limited (and not of "broad" interest) and therefore of interest not primarily for literary reasons but for its sociological or quasihistorical interest. The "regionalist" is a second-rate fictioneer, a documentary-maker manque" (53). However, WH offers more than a regional novel can offer. Thus it is a wrong-headed assumption that Emily Bronte was confined to a small world of the moors and thus unresponsive and inattentive to the world that lies beyond.

Although the setting is a secluded place, the fictional world of the novel is not untouched by the cultural, political and social events of its time. WH reproduces the microcosm of the society in an ideological landscape. Earnshaws, Lintons, Heathcliff and Lockwood represent different layers and facets of social structure as Carol A. Senf puts it: "The Earnshaws, yeoman farmers, are the remnants of an earlier historical period; the Lintons, landed gentry, are the ruling class at the time the novel was written; and Heathcliff, an odd and seemingly contradictory mixture of primitive nature and modern capitalism, is the power of the future" (204). Christopher Heywood, on the other hand, identifies WH as "the anti-slavery discourse" of the early nineteenth century Britain because of Heathcliff"s rejection to be placed in the lowest level of social hierarchy (qtd. in Cory 1). After Mr Earnshaw`s death, Hindley subjects Heathcliff to the conditions of slavery "insist[ing] that he should labour out of doors instead, compelling him to do so, as hard as any other lad on the farm" (36). Heathcliff"s "non-European otherness" highlights the colonial perspective which also suggests "the social inversions staged by early nineteenth-century slave rebellions" (Beaumont 141). Terry Eagleton in his article "Heathcliff and the Great Hunger" (1995) also studied WH in the light of the Great Irish Famine and describes Heathcliff as an "insurrectionary" who rebels against his place in the social hierarchy. To Eagleton, Heathcliff"s gaining wealth, power and social status can be considered along with his insurgency "revolution from below" which can be likened to "the various stages of the Irish revolution" against Britain in the 1840s (18-20).

Bronte wrote this novel in the 1840s while England was undergoing rapid industrialization and urbanization, and Ireland was resisting against the British imperialism by launching Young Ireland Movement of independence. During the late 1830s and 1840s in England, Britain witnessed a social upheaval that shook the capitalist and patriarchal structures from their roots, threatening the stability and sustainability of the system. Abbie Cory regards the reform and revolutionary movements of Ireland for the equal distribution of socio-political power, the 1832 Reform Bill and working-class agitation against the 1834 Poor Law as the greatest challenges the British State was ever faced with. Women played an active role in the Young Ireland Movement which aims to abolish the 1800 Union between England and Ireland in the struggle against the dominant power structures of the state. Inspired by this movement, Emily Bronte creates strong and rebellious female characters who resist against their objectification and docilization by calling into 
question class and gender-based systems of power. For this specific reason, the characters, though situated in Yorkshire, should be construed in a far-reaching nationwide social, political and cultural context with references to current events.

\section{Wuthering Heights as a Novel of Warfare: Exploration of Class and Gender issues}

Emily Bronte boldly touches on the class and gender issues, most of the $19^{\text {th }}$ century female writers preferred to ignore since they were afraid of the reactions of male critics in a male-dominated literary world. With the wild departure from domestic realism, WH shatters not only Victorian social ideals but also turns upside down the idea that domestic household offers security, harmony and contentment for women. Women no longer depend on men for fullness and completion in $W H$. Instead, what they have is domestic disorder and troubled household in a ruptured family structure. Catherine, Isabelle and Cathy strive to go beyond the hegemonic hierarchies based on class and gender. The mayhem in $W H$ results from the blurring or the removal of the strictly maintained boundaries and hierarchies between social classes, races and genders. Heathcliff, for instance, seems to be a gentleman but his dark skin creates a contrast to his newly gained gentlemanly appearance, which uncovers his low class origin, in spite of which Heathcliff comes in line for an inheritance of the Heights. On the other hand, the ill-mannered, coarse, uncivilized Hareton, although the rightful inheritor of Wuthering Heights, is reduced to a common laborer but lives under the same roof with the refined and cultivated Cathy and gentlemanly looking Heathcliff. Traditionally assigned gender roles like motherhood, wifehood and sisterhood are also rejected by Catherine, Cathy and Isabelle to develop a new model for femininity. Cathy, lacking feminine domesticity, deliberately fails to show any sign of hospitality to Lockwood. On the contrary, she stares at Lockwood "in a cool, regardless" and unladylike manner, which Lockwood finds "exceedingly embarrassing and disagreeable" (8).

The critics such as James Phillips see $W H$ as a novel of love, displaying "the distinct components of love" (97). Phillips interprets even the cruelty of the male characters as an expression of "absolute love" (101). However, WH is a novel of warfare launched against women and spaces associated with women, home and nature, as enemies to be conquered by men to prove their superiority, authority and power. Bronte offers a harsh critique of androcentric misogyny prevalent in the 19th century that is made visible in the novel through a murderous competition Heathcliff and Edgar have for more profit, wealth and progress at the eve of industrial-capitalist age. Such a perfectly isolated part of the countryside is reproduced as a microcosm of capitalist society in which Man`s value is measured and determined by property and wealth. Emily Bronte witnessed capitalism's exploitative practice when Yorkshire had been changing as a result of the cotton and mining industries in the 1840s and Poor Law riots took place in Halifax in 1837 and 1838 where she was teaching. The secluded community on the moors is not away from the destructiveness and corruption at the threshold of the 19th century. Heathcliff, Edgar and Hindley are motivated by egocentric ethics which is born out of the growthoriented capitalistic economy and they assume the position of a usurper of love, body, property and rights.

Bronte makes use of the correspondence between female body, building and landforms in order to display the interconnections and interdependence between different forms of violence. So whether the target of the war is a woman, nature or property makes little difference to men. Nature and home are gendered as female and thus should be subdued into man's service. Various strategies Heathcliff and Edgar employ go hand in hand to conquer, possess and control domestic households, external nature and body since the war against nature, home and women passes through the same stages: objectification, commodification, conquest, possession/ownership and control. Their strategies include reductionism, separation, physical and emotional uprooting, masculinization of nature and household, brutalization and destruction of female interconnections.

Throughout the 18th and 19th centuries, the romanticized and idealized womanhood produced by men's desires as a "complement to the strong, enterprising, bourgeois white man who began to conquer and colonize the world for the sake of capital accumulation" (Mies and Shiva 135) determines the man-woman relationship. A portrayal of a good woman is based on the destruction of strong, independent and self-sufficient women so that the image of a weak, submissive and sentimental woman who needs protection and guidance could emerge. She is the mother, and the embodiment of feeling, caring and humanness. This image of womanhood contradicts to the new capitalist man who has to compete with other men to gain wealth. The desire to obtain private property is closely related to the growth and profit-maximization approaches of capitalism.

That Heathcliff is a representative of an opportunist, Machiavellian capitalist man does not receive enough attention. Heathcliff has very often seen as the embodiment of animalistic side in human psyche not only by the critics but by the other characters in the novel. Nelly, for instance, depicts him as howling "not like a man, but like a savage beast being goaded to death with knives and spears" (122) and Catherine as "wolfish man" (74). There are also references to his "sharp cannibal teeth" (128) and his evil darkness. Piciucco sees Heathcliff as a "fairy-tale monster", "werewolf", and "ogre" (223). Marianne Thormahlen identifies Heathcliff as a Faustian hero who has a pact with the devil. However, Heathcliff originally does not belong to the Heights or farming culture there but comes from Liverpool and he brings along with himself competitive, combative capitalist values. His coming to the Heights can be taken as the intrusion of destructive capitalist values which disrupt and unstabilize the agricultural and rural life. Heathcliff has been molded into what he is especially during the period of his three-year absence in the city, obtaining the devices and values of capitalist-industrial patriarchy. He, the incarnation of the intruding menace, transfers the values of industrialized and urbanized city life to the agrarian country life. His first capitalist competition, however, becomes apparent even before he leaves the Heights to be transformed into an irredeemable capitalist when he blackmails Hindley to exchange their horses: "You must exchange horses with me; I don't like mine, and if you won't I shall tell your father of the three thrashings you've given me this week, and show him my arm, which is black to the shoulder" (30-31). 
Man`s zeal for ownership objectifies nature, land and female body, which precipitates subordination and decreation. The ambition to pass land on along with its ancestral and monetary value is one of the reasons of the conflicts that arise between Heathcliff and Edgar Linton. Heathcliff and Edgar try to dominate and violate Trushcross Grange and Wuthering Heights by penetrating their interiority by using force. Considering the fact that the household was seen as a female realm in the $19^{\text {th }}$ century, this trespassing from the male domain into the female domain can be taken as an act of rape. Women who are reduced to a form and shape and understood in bodily terms rather than content or function are associated with buildings. Through displacement, women and their bodies, just like estates, are reduced to a private commodity to be possessed in the same way common lands are fenced and enclosed to be made the objects of private ownership. Heathcliff is also trying hard to take the possession of the houses as a substitute for unrequited love and obsession for Catherine and unfulfilled sexual consummation with her.

The struggle for ownership over the properties function as the symbol and means for the struggle for ownership over the displaced female bodies which are passivized and objectified as disposable objects by being reduced to raw materials from which men can extract what women are capable of giving. Female bodies are treated as land in which a seed is implanted to get harvest and the final product to be obtained is a child. The on-going war is extended to include children since to keep Hareton, Cathy and Linton are necessary for the fathers to guarantee that what they have possessed will not pass to other hands. It is also a proof of their possession and control over the female body which they assume should belong to them.

The fierce contention between the male characters over the usurpation of nature and home leaves female characters more defenseless and susceptible to subjugation and exploitation. Catherine, Cathy and Isabelle are separated from their domestic households and nature. Catherine's separation should not be read as a self-imposed exile. Catherine is first dispossessed and denied power and authority in her childhood by her father who fails to bring a whip to Catherine and as a substitute, she gets Heathcliff. She is further victimized in the rivalry between Hindley and Heathcliff. What pushes Catherine to take side with Heathcliff is the necessity to stand strong against her brother's despotism. Lockwood reads her account of Hindley's behavior in her diary: " 'You forget you have a master here, 'says the tyrant. 'I'll demolish the first who puts me out of temper!' " (16). Catherine describes Hindley as a "detestable substitute" whose "atrocious" conduct brings both Catherine and Heathcliff on the verge of rebel: "We took our initiatory step this evening". She does not accept Hindley`s authority: "how dared he?" (16). Catherine also rejects strict religious upbringing and patriarchal teachings imposed on her by destroying the religious texts she is forced to read and by spending Sundays on the moors rather than in the church.

Heathcliff who is named after a dead Earnshaw son might be the illegitimate child of Mr. Earnshaw. This is how he justifies his acts of brutality to seize the property. There is a conflict over the legitimate and rightful ownership over Wuthering Heights among Hindley, Catherine and Hareton. Heathcliff feels he has been put at a disadvantage by birth and like Edmund in King Lear, he is full of hatred to pursue revenge with determination to inflict persecution and execute justice, thus he severely disturbs the domestic balance and familial bonds with deliberation. Catherine is subordinated and expelled from Wuthering Heights by Hindley who cannot endure seeing her around because of her intimacy with Heathcliff. Furthermore, Heathcliff"s claims of ownership and domination over Catherine to gain advantage over Hindley in their power relation by stealing his sister away from him after the death of his father make her want to go away urgently. Catherine is absolutely denied a place in Wuthering Heights and after her realization that Heathcliff will not be any better than Hindley, she turns her attention to Edgar. Catherine's choice of Edgar as her husband is a strategic tactic because he is both physically and emotionally weaker, so can be more easily managed. To Catherine, Edgar is a whiny boy: "Edgar is sulky, because I'm glad of a thing that does not interest him...I gave a few sentences of commendation to Heathcliff, and he, either for a headache or a pang of envy, began to cry: so I got up and left him" (76). Moreover, since Catherine does not feel any strong feeling or attachment for Edgar, she can practice resistance and subversion with no trouble or difficulty. Her marriage with Edgar disconnects Catherine from Wuthering Heights.

The fierce and violent battle between Edgar and Heathcliff over the possession of Catherine, then over Isabelle and finally over the properties is ignited when Heathcliff starts to see Edgar as a rival after the growing friendship between Catherine and Edgar. Catherine, once his property, is stolen away to be owned by Edgar, thus Isabelle should be taken as a substitute. By uprooting Isabelle from Thrushcross, Heathcliff avenges Edgar who causes him to lose the fight against Hindley by marrying Catherine. Displaced Isabelle and Catherine are "transplanted into unsuitable soil" (Williams 114) and fade away. Edgar and Heathcliff see marriage as the territory of male domination and possession where they can claim ownership over the body and property. Heathcliff shows an interest in Isabelle just as Edgar's belonging. Isabella soon discovers that her marriage offers nothing more than a prison life as Heathcliff makes it clear: "you're not fit to be your own guardian, Isabella, now; and I, being your legal protector, must retain you in my custody" (189).

Heathcliff and Edgar have a tendency to reduce not only women but also children to the status of properties whose ownership belongs to men because children are seen closely connected to and extension of their mothers. Men are provided with rights to keep children and women as captives under the pretext of legal custody and guardianship rights. In the 19th century, according to the general rule of law in England, the legal power over infant children was given to the father, and the mother was entitled no power or right when he was alive. The father had an absolute right to the custody of his child even if the child was being breastfed. This law reduced the child to the status of a property like the other wealth, including estates, houses and lands that exclusively belonged to the father. Laura Berry states that the 19th 
century "law treated all persons only in relation to property" (34). Heathcliff abuses his legal rights to custody to take over the properties and he extends his revenge plan to include young Cathy and Hareton since he sees Catherine as Edgar's property and Hareton as his father's possession. Linton, of course, should belong to him as his own son too. Heathcliff refers to Linton as 'my property' (159) which/who will add up to the accumulation of his wealth: "He's mine, and I want the triumph of seeing my descendant fairly lord of their estates; my children hiring their children to till their father's land for wages" (160). Like the female characters, young Linton is also disconnected from Thrushcross Grange to be harassed and imprisoned in Wuthering Heights by Heathcliff. The struggle to possess Linton becomes more meaningful when his feeble, weak and sickly nature is considered. He does not fit into the description of what man is like by patriarchy and because of his feminine features he is categorized along with the other female characters and he is exposed to the same treatment.

Heathcliff"s hatred for Hareton and Cathy is also immeasurable since he sees Catherine in both of them: "They lifted their eyes together, to encounter Mr. Heathcliff - perhaps you have never remarked that their eyes are precisely similar, and they are those of Catherine Earnshaw" (244). Hareton is deliberately left illiterate and turned into a rough, coarse, unsophisticated farm worker as Catherine observes him in the kitchen: "He`s just like a dog, is he not, Ellen? ... He does his work, eats his food, and sleeps, eternally! What a blank, dreary mind he must have!" (235).

Homelessness is created through the destruction of ecological home and the physical and emotional uprooting. The word ecology was derived from oikos, which means a dwelling place, home and household (Mies and Shiva 104). Isabelle, Catherine and Cathy can be more easily owned and controlled when they are pulled out and disconnected from their both sociocultural and natural homes. Female characters are made nomadic, placeless and homeless with no sense of belongingness. Male usurpation of nature and home leads to the destruction of female rootedness, creating conditions of insecurity and vulnerability. Denied a strong emotional attachment to places, the female characters have lost their sense of relationship to places and to other people and thus go through psychic damage.

Not only the female characters are displaced from their domestic households and nature but also the female bonds are broken. They are made enemies to each other through the destruction of interconnection, interdependence and reciprocity between them. Nelly takes sides with Heathcliff and Edgar against Catherine. She describes Catherine as "mischievous and wayward" (33) and later after her transformation into a young lady as "haughty", "headstrong" and "proud" (51). During Edgar`s visit to Catherine at the Heights Nelly intentionally provokes Catherine to misbehave, which results in her pinching Nelly so that Edgar can be exposed to her unruly, spiteful behavior and untrainable nature: "Miss is dreadfully wayward, sir!... As bad as any marred child" (56). Cathy can "beat Hareton, or any child, at a good passionate fit of crying" (66), and during her last illness she is "no better than a wailing child" (96). Nelly does not feel any sympathy for the sufferings of Catherine. On the contrary, she openly acknowledges that "I did not like her, after her infancy was past" (51). To Nelly, Catherine is morally inferior and wicked when compared to Edgar and Heathcliff: "He [Edgar] was kind, and trustful, and honorable; and she - she could not be called the opposite, yet she seemed to allow herself such wide latitude, that I had little faith in her principles" (83). Nelly, serving the patriarchy, helps both Heathcliff and Edgar to imprison Catherine, to which Catherine raises a strong objection: "The Grange is not a prison, Ellen, and you are not my jailer" (185). Nelly does not function differently from Joseph as a prison guard in this regard. The relationship between Catherine and Isabelle is no better. Catherine attempts to protect Isabelle who mistakes Heathcliff for a romantic hero from his ill-intentioned advances by openly telling her that she is "surely losing [her] reason" and by describing Isabella's confessed love for him as "idiocy" (79) and "madness" (79): "Pray, don`t imagine that he conceals depths of benevolence and affection beneath a stern exterior! He's not a rough diamond-a pearlcontaining oyster of a rustic: he`s a fierce, pitiless, wolfish man ... he`d crush you like a sparrow`s egg, Isabella, if he found you a troublesome charge" "(80). But Isabelle blames her for desiring no one to be loved but herself. Catherine scolds and warns Heathcliff also for seducing Isabella not only out of jealousy but also because of her concern and care for her: "I'm not jealous ... If you like Isabella, you shall marry her" (87).

The sense of placelessness and homelessness along with the dissolution of female solidarity is aggravated by transforming home and the natural world into an imprisoning, entrapping, dominating and tyrannical web for women. After the loss of the control of the household and nature to male authority, nature and home cease functioning as places where the female characters can exist themselves. Home under the care of men turns into a prison where women are held as captives. Enclosure, spatial reduction, the claustral atmosphere have been used both in the $19^{\text {th }}$ and $20^{\text {th }}$ centuries to objectify the sense of confinement. In "Repression and Sublimation of Nature in Wuthering Heights" Margaret Homans argues that the closed house represents entrapment: "the entrapment of the soul by the body, the entrapment of society and convention, and the entrapment of one character by the will of another" (8). Female characters are bodily, mentally and emotionally confined indoors (9-19). This sense of confinement is intensified by an abundant number of references to the doors, windows, locks, hedges, gates, and threshold (Crouse 179-189). Even Catherine's bed is enclosed. "I thought [...] I was enclosed in the oak-panelled bed at home. [...] My father was just buried, and my misery arose from the separation that Hindley had ordered between me and Heathcliff — I was laid alone for the first time" (125). Heathcliff, turning into an abusive tyrant, redefines and reconstructs Wuthering Heights as a prison where he keeps Isabelle and Cathy by force as the new owner of the property and so the domestic security, comfort and joy are replaced by confinement and captivity accompanied with cruelty. The limitation of space and confinement refers to sexual unfulfillment as well. As Lutwack asserts, "Sexual relations with lovers and husbands diminish as space and movement become more confined. Restricted movement is regularly associated with sexual deprivation" (97). 
The construction and representation of nature in $W H$ deserves more in-depth and critical attention and analysis that should go beyond the limitations of earlier interpretations and conceptions. Relph maintains that "common latenineteenth century attitudes [...] understood landscape as an object for casual contemplation and the development of sentimental associations, something to be indulged in by daughters of the nouveaux riche" (41). In $\mathrm{WH}$, nature has been examined in several different ways and the common understanding most of the critics come up with is that it is hardly possible to mention the real nature, even as the frame or background. The focus in this view has been placed on the use of nature for the psychological revelation of the characters' repressed feelings and suppressed sexuality. So, nature has generally been taken as a presence mirroring the inner worlds of the characters or as a frame device to implicate the meteorological states of mind of the characters in $\mathrm{WH}$.

However, this approach is very simplistic and restrictive. The nature in $W H$ does more than to reflect the moods of the characters to reveal unfulfilled passionate love, unsatisfied lust or the wrath of revenge. The fact that nature is ideologically and politically laden has been either turned to a blind eye or underestimated so far. Thus, Bronte's representations of nature should be examined from the lenses of gender, class and race because these representations contain misogynist, classist and racist elements, and the otherizations of the non-white and the rebellious female are realized through nature.

The geography which is characterized by limestone hills with a barren, uneven "non-picturesque but fertile moorland" (Heywood 18) surrounding a farmhouse at the Heights among hillocks and banks, "beck, cave, glen, village", and the Grange in the valley has received a lot of attention. The landscape in Yorkshire is formed after the volcanic eruption, and earthquakes and volcanoes are taken as evidences of creative energy of nature. Heywood portrays the moorland landscape "as a source of life and regeneration" (19). Bronte Matthews suggests that Emily Bronte construed the moorland "as a source of regeneration for a society corrupted by slavery and its moral counterpart, enslavement to appetite, egoism, and passion". The moorland excursions help Cathy to assume the role as an emancipator of both the properties and nature monopolized by the men by restoring the disruption afflicting her mother's generation.

In Western culture, nature is generally gendered as female. Annette Kolodny in her work The Lay of the Land maintains that gardens and forests are the places to which gender and ownership are assigned. Woman is earth, garden, forest, moors, valleys and caves and thus enemy which must be forced into man's service (Mies and Shiva 95). In $W H$ the moors occupy the central place. The Western culture has taken an ambivalent attitude towards wilderness since as a cultural and ideological construct, the meaning of nature depends on given historical and socio-political contexts. Because of the conflicting attributes assigned to wilderness throughout history, it assumes the characteristics of a hermaphrodite. While the tamed, cultivated nature is celebrated as the glorious achievement of man`s domination, wilderness is associated with the unmanageable and demonic power of women. Wilderness, when viewed in negative terms as the source of darkness, evilness, and destructiveness, is marked by bleakness, danger and isolation.

However, in the $19^{\text {th }}$ century the attributes which characterize manliness and maleness including forcefulness, violence, wildness, competitiveness and sexuality indicate closeness and identification between not women and nature but men and nature. Wilderness, seen as a realm of man, is a place men go for their sports activities like hunting or a place for adventure so that they can satisfy their ego by conquering what is vast and uncontrollable. Norwood asserts that man sees wilderness as a "place for defining virility, for playing out aggressive, adventure-seeking, sometimes violent impulses. Survival in a hostile natural environment is an ego-gratifying achievement and feeds the achievementoriented male psyche, enabling men to return to civilization and improve their culture. Nature is preserved because it is useful to culture" (323).

In this context, females are excluded from wilderness. Cultural stereotypes and physical hardships are used to keep women away from nature and they are prevented from getting first-hand, direct experience in wilderness and instead encouraged to search for bliss, fulfilment and peace in civilized domestic domains created by males for them. In Victorian novels, social orders reject wilderness and extreme nature by exalting hearth and cultivated fields. As Levine suggests, the heights are where society is not (137). There are taboos against women's participation in any but civilized nature since they are thought to be more comfortable inside or in civilized gardens and cultivated nature (Norwood 324). Catherine is forced to choose domesticity with an organic connection with a civilized society, limiting herself to the male-defined female role as the follower and carrier of patriarchal culture. The nineteenth-century bourgeois ideology insists that "both a morally uprighteous mother and a healthy natural environment were necessary to produce a healthy child" (Merchant 245). The woman as a mother and wife is expected to instil morals and ideals of culture and civilization in her children and husbands at home. The absence of motherly figures in the novel is obvious. When the novel opens, the mothers of Catherine and Isabelle are alive but they are shadowy figures left in the background. They both lose their mother when they are young. Cathy, Linton and Hareton are also left motherless. Motherless households are dominated by men. This motherlessness causes wilderness to reign over a social life, especially in Wuthering Heights like noxious weeds spreading all over the cultivated garden or field, against which men wage a war.

In the novel there is no real nature untouched by human; both wilderness and cultured nature emerge as the constructs of white man. Wild nature functions as the antagonist to white male western culture. White wilderness is preserved and imposed on nature by white man as his Other through and against which he can define himself as cultured and civilized. The fear of men that women would infringe in the wilderness stems from their fear of the other's power. In other words, the aggression of white men towards women and nature originates from their failure to tame and dominate the other. The Great Chain of Being and intellectual and scientific developments from the Renaissance and Enlightenment onwards have established white man as the Lord and possessor not only of mankind but of the entire universe. White 
man takes the privileged position of a speaking subject and reduces nature and women to silence and passivity as the inferior Other. Hence, men need women and wilderness for their ego-gratification, self-definition and a sense of achievement through conquest and domination.

Unlike in Wordsworth's poetry, wilderness does not function as a source of cultural education, personal growth, contemplation but as social, class and racial exclusivity in $W H$. Not only misfit and subversive female characters, as different breed of femininity like Catherine and Cathy, but also the non-white like Heathcliff and the social outcast like Isabelle who fails to act according to the ideals of her social class and gender are identified with the uncontrollable, hideous, and malignant aspect of nature. In the novel the social and ideological construction of the non-human world along with gender and race is grounded on the patriarchal and androcentric logic of domination. The masculine subject asserts himself through the negation of the other. Lawrence Buell in his work Environmental Imagination states that nature has been otherized twice in modern mindset. Since human interests have primacy, nature needs to serve as "a symbolic reinforcement of the subservience of disempowered groups, nonwhites, women, and children" (21). Likewise, Plumwood states that "the category of nature is a field of multiple exclusion and control, not only of non-humans, but of various groups of humans and aspects of human life which are cast as nature" (14). She also adds that racism, colonialism and sexism spring from sexual, racial and ethnic differences and body women and nature are identified with is constructed as "a sphere of inferiority", a "lesser form of humanity lacking the full measure of rationality or culture" (4).

Catherine emerges as the spiritual and physical embodiment of the moors. She rejects to be tamed and domesticated and counterattacks such attempts with more effective maneuvers. The moors are the only place for Catherine to experience joyous moments of relief and freedom as Nelly observes: "It was one of their [Catherine and Heathcliff] chief amusements to run away to the moors in the morning and remain there all day" (36). What makes the moors an Edenlike place for Catherine is the fact that the moors are not managed or restricted by the norms and taboos a patriarchal society endorses. Thus it emerges as a female zone. In the moors, she is not an object to be possessed or dominated but a liberated, independent subject free to experience her emotions without paying attention to social and gender decorum and propriety. However, both the mother and the daughter, Catherine and Cathy, who are very much devoted to the moorlands are denied access to the moors by the established patriarchy, Catherine by his brother Hindley and Cathy by his father. Although Cathy is strictly forbidden to go to the moors, like her mother she cannot overcome her attraction to the mysterious realm of the moors with her strong yearning to explore Penistone Craggs as soon as paternal authority is removed. While Cathy is rambling on the moors to find birds' nests, Nellie as the guardian of patriarchy, tries to redirect her to a cultivated nature: "The moors, where you ramble with [Edgar], are much nicer; and Thrushcross park is the finest place in the world" (146). However, this freedom does not last long and on her way to the Craggs, Cathy stops at Wuthering Heights and cannot go any further.

This female zone which stands for dangerous passions and Romantic excesses becomes one of the male targets and comes under attack and siege of the husbands, brothers and lovers who are disturbed by liberation, freedom and happiness the moors provide for women. The female characters who take enough courage and determination to transgress the boundaries of patriarchy are chased and hunted in the moors. Thus with the interference and modification of patriarchy, the liberating moors are turned into an entrapping web. In a beautiful spring day Cathy is tempted to break bounds by roaming on the moors which results in abduction, entrapment and harassment in the Heights. The female characters need nature as an alternative to the existing social system founded on the unjust family and property law which granted the possession of child and property to men with complete control and exercise of power by depriving women of legal rights and making them completely dependent on their husbands for access to their children and property. Encouraged by this law, men did not see any wrong in ill using both their wives and children.

C.S Lewis states that "what we call Man's power over Nature turns out to be a power exercised by some men over other men with Nature as its instrument" (28). Bronte`s female Nature is forced to undergo a masculinization process and turned into the landscape of power, a place that shows the reconfiguration and appropriation of nature as property. As a result, nature becomes blunt and indifferent to the sufferings, miseries and worries of the female characters while it is very responsive to male emotional and mental situations. When Heathcliff leaves Wuthering Heights after overhearing the conversation between Catherine and Nelly, the violent storm knocks down the tree that hits the house. Nature here empathizes with and expresses the psychological state of the male character. When Catherine dies, the spring turns into winter not to mourn over her death but as the reflection of male characters' grief: "On the morrow one could hardly imagine that there had been three weeks of summer: the primroses and crocuses were hidden under wintry drifts: the larks were silent, the young leaves of the early trees smitten and blackened - And dreary, and chill, and dismal that morrow did creep over!" (130-131). Morton states that

Rugged, bleak, masculine Nature defines itself through extreme contrasts. It's outdoorsy, not 'shut in'. It's extraverted, not inverted. It's heterosexual, not homosexual. It's able-bodied ---'disability' is nowhere to be seen, and physical 'wholeness' and 'coordination' are valued over the spontaneous body [...] Nature is aggressively healthy, hostile to self-absorption. It is allergic to semblance [...] There is no room for irony, no room for anything more than superficial ambiguity. Things should mean what they say and say what they mean. There is room for humor, except perhaps a phobic, 'hearty' kind. Masculine Nature is the operating system of the authoritarian personality. Masculine Nature fears its own shadow - subjectivity itself. $(82,83)$ 
Such nature reveals the distribution of power in the social order, promoting a set of aristocratic beliefs about the innate and positional superiority of the white western upper class, which solidifies social hierarchies between sexes, classes and races. Serving dominant socio-cultural principles and organized around class, race and gender-based ideologies, masculinized, anthropomorphized and androcentric nature has been turned against female characters to be punished either for their attachment to Heathcliff or for their free spirit.

Here come the constructions of Wuthering Heights and Thrushcross Grange. Preindustrial society is represented through a country house where a wealthy family lives with their tenants, neighbors, clergyman, shopkeepers and artisans. Estates or houses represent family distinction, social status, manners, moral codes, individual character or society. A well-ordered way of life is conveyed with a sense of well-defined place that is blessed with natural as well as man-made beauty. While garden refers to nature perfected by God or by man, wilderness, forest, desert, mountain, sea etc. are seen as formless matter. In the novel while Thrushcross Grange is reflected as the Garden of Eden created on Earth by civilized men, the moors and Wuthering Heights are depicted as places where people end up after falling from the Garden of Eden. Wuthering Heights surrounded by the moorlands is located at the bleak hill-top while Thrushcross Grange in a pleasant valley. When Lockwood pays a visit to Wuthering Heights, we have a chance to take a closer look around and the place is covered by wild weeds and dead rabbits. Wuthering Heights and Thrushcross Grange seem to be the embodiments of two polarized sets of antithetical characters, referring to Cartesian dualities between mind/body, spirit/matter, culture/nature. These two households have been described in terms of binary oppositions including "the land of storm and the home of calm" (Cecil), "Hell and Heaven" (Gilbert and Gubar), "the Sexual and Spiritual" (Prentis), "classless society and hierarchical society" (Winnifreth), "disappearing farm culture and emerging Victorian gentility" (Q. D. Leavis), "savagery and civilization" (Reed), "patriarchal society and negated feminine authority" (Lavabre) (qtd. in Levy 159).

In this sense, this novel can be seen as the war between culture and nature, between wild nature and domesticated, civilized nature as male culture defines itself against nature. Nature, through masculinization, has been sacrificed to give voice to the violent aspect of male-dominated culture and civilization which excludes rather than includes. Nature has been transformed into a puppet to fulfil the malicious intentions of patriarchy and assumes the role of the servant of the culture in order to be utilized as a patriarchal tool of discipline and punishment and the instrument of oppression. Nature now functions as the back-up voice of social conventions and moral teachings of patriarchy. In the novel, the possibility of the union of love and marriage between the white and the non-white is given in an apocalyptic narrative as if it is something dreadful and nightmarish. It is nature which does not let the interaction between the self and other, between the white and the colored or between wealthy class and low class. The heights are discordant and incompatible with the ordinary life and ordinary human feelings. Thus, the harshness and cruelty of Wuthering Heights is not the manifestation of the passionate love between Heathcliff and Catherine but the impossibility of the consumption of such love. Shifted from the position of the otherized to otherizing, wilderness confiscates rebellious female characters who violate the taboo codes of gender, social class and race. Isabelle has been penalized for her transgression of culturally established racial and class boundaries and she has been exiled to untamed, uncivilized nature and exposed to the hostility of this malevolent nature. On the other hand, Catherine gets tamed and enjoys the civilized nature of the Grange as a reward for her rejection of Heathcliff: "The contrast resembled what you see in exchanging a bleak, hilly, coal country for a beautiful fertile valley" (54).

Not only nature but also animals are used as servants of culture to teach the Other the rules of the society. The bulldog that bit Catherine, as Gilbert and Gubar suggest, represents the patriarchal oppression which she is obliged to surrender at the Grange, and Catherine's coming to the Grange is a "sinister ritual of initiation" which has caused her to lose her "childhood innocence". Dogs as the guardians of society protect the cultural territories against the intrusion of others so that no voluntary connection can be established. When well-preserved territories are transgressed willingly or unwillingly, this inclusion and interaction turns out to be captivity, detention and incarceration. Catherine's being bitten by the dog in Thrushcross Grange is a punishment given to her by heterosexual and capitalist patriarchy which offers civilized and cultivated life as a cure for transgressions and subversions of social decorum, conventions and taboos. After Catherine is introduced to socially acceptable life, she is taught to celebrate it by acquiring the attitude and manner necessary to be a typical and conventional lady. The price she has to pay for this is the suppression of her unique individuality. She has to sacrifice her authentic self to earn the forgiveness of patriarchy. Sandra Gilbert and Susan Gubar interpret Catherine's entrance into Thrushcross Grange as a kind of initiation into adult womanhood. However, Catherine does not end up in attaining traditional proper female merits. Hers should be regarded as an intrusion into domestic traditions of civilized society to destabilize and unsettle it.

\section{Resistance and Liberation for Women in Wuthering Heights}

Bronte does not draw her female characters as weak, easily manipulated and controlled, unable to defend and protect themselves as usually assumed. Despite all the efforts of patriarchy, Bronte ends the novel with a promise that women can overcome the external nature turned against them by reclaiming their bodies and home along with nature. The experiences of Catherine and Isabelle open the path for self-discovery and emancipation for Cathy. Catherine and Cathy`s rages are unprecedentedly and revolutionarily "innovative" (May 418). To Cory WH is such a revolutionary novel for dissolving the boundaries (24). He also draws attention to "the momentary resistances to class and gender", especially by Catherine Linton and Catherine Heathcliff as "insurgents against hegemonic views of gender roles and bourgeois marriage" (Cory 6). 
Reparation and mending come from Cathy who has inherited her mother's free spirit and rebellious nature. It is she who negotiates Wuthering Heights to Thrushcross Grange, the moors to the cultivated, enclosed garden, nature to culture and wilderness to civilization. Initially, she makes fun of Hareton's inability to read, and his coarseness arouses disgust in her: "The fool stared, with a grin hovering about his lips, and a scowl gathering over his eyes, as if uncertain whether he might not join in my mirth" (190). Hareton's rudeness and harshness is intensified by the lack of feminine influence on him. Cathy, like her mother, has learnt her lesson from her painful experiences with men and displayed the determination not to yield to male authority. In order to make sure that this will never happen, she, rather than accepting Hareton who is left out by patriarchy as he is, undertakes the task of educating him and helps him to acquire a new identity which will be freed from the oppressive influence of capitalist-oriented patriarchy and which will not threaten her freedom and desires under the pretext of improvement and training. To do so, Cathy wraps a book and asks Nelly to give it to Hareton as a gift to make peace with him: "And tell him if he' 11 take it, Ill come and teach him to read it right...and, if he refuse it, I'll go upstairs, and never tease him again" (238).

The union between Hareton and Cathy becomes possible when Cathy overcomes her mistrust and restores her broken faith to man by overcoming her class consciousness. Cathy's initial displays of hostility to Hareton or her unwelcoming approach to Lockwood do not make her 'wicked' or 'villain' or 'inherently evil and dark' but shows that her trust for men is irrecoverably damaged after having been betrayed both by Linton and Heathcliff. Although Cathy has had great faith in Linton's love, she is completely disappointed by his betrayal: "I believe I might kill him, and he wouldn't wish to retaliate [...] You wouldn't hurt me, Linton, would you? You wouldn't let any enemy hurt me, if you could prevent it? I'll believe you are a coward, for yourself, but not a cowardly betrayer of your best friend" (76, 203). The female dog that attacks Lockwood is also symbolically suggestive: "I flung her back" (6), mirroring Cathy's anxiety and concern over the intrusion of new patriarchal values based on industrial capitalism in $W H$. Lockwood's aggressive violence to the female child in his dream vindicates Cathy's concerns: "As it spoke, I discerned, obscurely, a child's face looking through the window. Terror made me cruel; and finding it useless to attempt shaking the creature off, I pulled its wrist on to the broken pane, and rubbed it to and fro till the blood ran down and soaked the bed-clothes" (20).

At the end of the novel, Cathy gains the ownership of both Wuthering Heights and Thrushcross Grange. Cathy has a chance to establish more egalitarian and feminine society with her newly gained economic power and social rank after Heathcliff's death as the new owner of the Wuthering Heights and Thrushcross Grange. It is possible to suggest here that Catherine eventually gets access to Wuthering Heights and the moors through Cathy and Hareton. The union between Cathy and Hareton does not restore traditional domesticity but interconnects and interrelates everything that has been kept apart and excluded before. Their relationship that challenges the established male-controlled family structure and land-based patriarchy is "neither obsessive nor self-obliterating, neither necrophilic nor incestuous" (Baldys 63). Cathy and Hareton owe this promising and rewarding future to Catherine's inspiring, rock-solid determination to fight not to be possessed and subordinated by capitalist patriarchy.

Some critics harshly criticize Catherine for her extreme self-obsession and selfishness. Narcissism is very often considered the main motivation for her action and behavior (Piciucco 221). Stevie Davies describes Catherine as a typical narcissist because of her "regressive, an instinctual, shielding attitude" (121). She does not give up on either the wealth, comfort and refinement Edgar provides for her or the passionate love Heathcliff has for her. She disseminates misery and desperation, first by killing the Linton parents and then bringing about destruction to the two men who love her and lastly by ruining Isabelle's life. In these interpretations, Catherine is sacrificed as a scapegoat to justify the unthinkable monstrous acts of Hindley, Edgar and Heathcliff who do whatever they do for the sake of victory and material gain necessary for their ego-gratification.

Catherine is overwhelmingly the biggest challenge Edgar and Heathcliff have ever been faced with. Sandra Gilbert states that $W H$ deconstructs the myth of The Beauty and The Beast through Catherine who should be read as a rewriting of Beauty. Catherine asks her father to bring a whip for herself from Liverpool while Beauty asks the father who will leave for a short trip to bring a rose for herself. Unlike a traditional heroine in a fairy tale, Catherine fails to show female domesticity, mildness and compliance to male authority, and she does not have self-sacrificial nature or "long suffering patience" (Piciucco 227): "On the contrary, they have sharp tongues and are not even intimidated by the threat of torture. They suffer from no lack of self-confidence or readiness to act" (Piciucco 227).

Many critics have been fascinated by the complexity of the characters who are analyzed and approached in different ways. Here we can start first by correcting the misreadings regarding the triangular relationship among these three characters. Phillips maintains that Catherine loves Heathcliff "while still a child and persists in loving him beyond the grave. He is the first and last object of her love" (102). Tytler declares $W H$ as "a world-famous love story" (180), and Catherine and Heathcliff as "the greatest lovers in the history of the novel" (167). According to Levy, Heathcliff and Catherine are actively at war with love in adult lives (159). Levy sees "distrust of love so painfully acquired in childhood, "misery inflicted by loneliness", "the suffering of loneliness", "the memory of loss", "the need of "intimacy", the pain and threat of "humiliating rejection", "exclusion", and "the pain of separation" as the main reasons for the conflict between the characters in their love relations $(160-161,173)$.

However, the relationship between the characters has nothing to do with romantic love or passion. Levy defines two types of defective love, unlove and overlove, and claims that Catherine and Heathcliff as the unloved are the victims of oppression and abuse they are exposed to in their childhood (159) while Edgar and Isabelle, who are overprotected and overpossessed, are suffering from overlove. This explains the characters' unhealthy and dysfunctional attachments to each other in their interactions. They are unable to differentiate real love from their emotional dependence on the others 
for the fear of loneliness, rejection, loss or abandonment (Levy 159). Some feminists like Sandra Gilbert and Susan Gubar, Joan Carson, Emile Montequt and Carolyn Heilburn view Heathcliff and Catherine as two conflicting sides of the divided self, "a hybrid monster" because of the popularity of the use of split characters in the $19^{\text {th }}$ century. Bronte's use of a male nickname and the terms "peculiarities" and "oddities" to describe herself are taken as the revelations of her androgynous inclinations. Bronte "encodes her sexual inversion in Heathcliff" (Kennard 24) and creates Heathcliff to represent her "masculine side", her "alternative self or double", "her other half": "I am Heathcliff-he's always, always in my mind - not as a pleasure, any more than I am always a pleasure to myself - but, as my own being - " (64). To Crouse, this remark of Catherine refers to "androgynous wholeness" between Heathcliff and Catherine which is broken after they are forced to take on traditional gender roles (190). Bernard Paris describes the relationship between Catherine and Heathcliff as "a mutual dependency" in which both characters lack "a sense of themselves as autonomous beings with separate identities" (108). Tytler explains that what attracts Catherine to Heathcliff is "the manliness she (mistakenly) supposes to be lacking in Edgar" (170).

On the other hand, Stonemen argues that the relationship between Catherine and Heathcliff does not fit into the courtship-and-marriage pattern, defined by Freud as the 'normal' path taken by a girl who finds a lover to replace her forbidden father by overcoming the Oedipus complex. Stonemen explains the Catherine-and-Heathcliff type of relationship by means of the earlier Lacanian stage of psychological development where all children seek for a "confirmation of their own identity in a mirror-image of themselves", which is found in the answering gaze of the mother, siblings or of another child (523). Catherine's comment that Heathcliff is "more myself than I am" (62) and that she is Heathcliff, is a utopian expression of a Romantic longing for the complete identification with the other. Catherine explicates the spiritual affinity she is trying to establish with Heathcliff as follows: "Whatever our souls are made of, Heathcliff's and mine are the same, and Linton's is as different as a moonbeam from lightning, or frost from fire" (62). So, Catherine's attachment to Heathcliff can be interpreted as a quest for a mirror image of herself. Heathcliff is the only person available and accessible to her since first the mother, later the father and lastly the inattentive, indifferent and self-indulged brother fail to function as a mirror image. When Catherine has Edgar and Isabelle at her disposal, her dependence on Heathcliff weakens.

Catherine's conduct is erroneously evaluated as narcissistic, egotistical, selfish, infantile or immature. Catherine in her renunciation of Heathcliff as a potential lover is neither "ignorant of the duties you undertake in marrying; or else, that you are a wicked, unprincipled girl" (64) as Nelly puts it. Catherine's most destructive feature is her desire and ability to have a controlling influence over all men (Przybylowicz 15). Catherine first utilizes the animosity between Heathcliff and Hindley to withstand coercion and abuse of her brother. In other words, what brings her closer to Heathcliff is her desire to resist against Hindley`s authority and cruelty. After the death of her father, Hindley orders separation between Catherine and Heathcliff. Catherine's decision to marry Edgar can be taken as an attempt to free herself and escape from Hindley's oppression and victimization. After Hindley has lost his wife and weakens his compulsion over Catherine, she struggles against Heathcliff's claim for ownership over her, which makes her turn to Edgar this time. Rejecting both Heathcliff and Edgar, Catherine gives up on her search for spiritual oneness and affinity and rejects to enter into the symbolic order ruled by the law of the Father. She denies Edgar and Heathcliff a consummation, leaving both sexually and emotionally frustrated and unsatisfied. Catherine acknowledges that "in my soul, and in my heart, I' $m$ convinced I'm wrong!" (61) in marrying Edgar. By marrying Edgar, Catherine has not betrayed her heart and love but she sets out to take revenge from both. She uses this patriarchal institution to her own advantage as a social and economic maneuver to empower herself and her rebellious nature does not let Edgar to claim ownership over her body even through marriage. The name Catherine has been inscribed on the ledge three times, each time with a different last name also reveals her subversive and transgressive fluidity; she can flow into and merge with different identities and feelings, challenging all the separations and boundaries. When Catherine tells Nelly "Who is to separate us, pray? ... Oh, that's not what I intend-that's not what I mean!" (63), she reveals her intention to enslave Heathcliff even after marriage. Catherine never lets Heathcliff"s and Edgar`s passion for her fade away or die out as seen clearly in the case of Heathcliff who suffers from monomania, a mental disorder of obsession common in Victorian times. As a seductress, she has a bewitching influence on both of them. Catherine reduces Edgar and Heathcliff to overdependent and needy creatures who are incomplete and unfulfilled without her:

What is not connected with her to me? and what does not recall her? I cannot look down to this floor, but her features are shaped on the flags! In every cloud, in every tree - filling the air at night, and caught by glimpses in every object by day, I am surrounded with her image! The most ordinary faces of men and women - my own features - mock me with a resemblance. The entire world is a dreadful collection of memoranda that she did exist, and that I have lost her! (245)

Although Heathcliff makes himself believe that Catherine`s love for him is much greater than her love for Edgar who is "scarcely a degree dearer to her than her dog, or her horse" (116), both Edgar and Heathcliff in their attempt to possess and dominate Catherine fall a prey to Catherine's trap. Heathcliff has never been able to digest his abandonment by her: "What right had you to leave me? What right - answer me - for the poor fancy you felt for Linton? Because misery, and degradation, and death, and nothing that God or Satan could inflict would have parted us, you, of your own will, did it" (125). Heathcliff is cursed and bewitched by Catherine to suffer for good beyond consolation: "Are you possessed with a devil ... to talk in that manner to me when you are dying? Do you reflect that all those words will be branded into my memory, and eating deeper eternally after you have left me? [...] Is it not sufficient for your infernal selfishness, 
that while you are at peace I shall writhe in the torments of hell?" (123). Heathcliff"s reference to Catherine as "my life" (122) and "my soul" (124) during their final meeting and immediately after her death shows his desperate fixation on her. Out of desperation, Heathcliff even prays Catherine to haunt him after her death. "You said I killed you — haunt me then! [...] Be with me always — take any form — drive me mad! Only do not leave me in this abyss, where I cannot find you! Oh God! It is unutterable! I cannot live without my life! I cannot live without my soul!" (129).

When Heathcliff returns to find Catherine married to Edgar, Catherine welcomes him like a lover. This is part of the game to bend them to her will and bring them at her mercy. She craves to keep them, but not for herself but for each other. Catherine makes use of undying rivalry and enmity between these two men by pulling them in the triangular relationship to put them against each other, forcing them to endure and tolerate one another although she knows that friendship is out of question between them. Catherine first abandons Heathcliff for Edgar and then rejects Edgar when he tries to prevent her from seeing Heathcliff. In her last meeting with Heathcliff she states that "you and Edgar have broken my heart" (122) to inflict sufferings and pains on them. Catherine sets the stage as a battlefield and draws them closer to the fight like moths attracted to the light. This intention of hers can be clearly seen when she locks both men in the kitchen, throwing the key into the fireplace: "I'm delightfully rewarded for my kindness to each! After constant indulgence of one's weak nature, and the other's bad one, I earn, for thanks, two samples of blind ingratitude, stupid to absurdity!" (89). The kitchen, as a female space, is where she can dominate and control them. Rather than playing the role of a peacemaker, she utilizes every opportunity to turn even small conflicts and tension into a big war between the two men. It is Edgar who raises an objection to their situation: "Will you give up Heathcliff hereafter, or will you give up me? It is impossible for you to be my friend and his at the same time; and I absolutely require to know which you choose" (92).

Catherine also takes advantage of their unforgiving nature and vindictive dispositions to make them pursue vengeance which will lead to the destruction of both the self and the other. Catherine brings their animalistic sides out so that they annihilate one another as self-consuming heroes. To keep their rivalry alive, she constantly compares and contrasts them. Heathcliff is what Edgar is not and Edgar is what Heathcliff does not have. Catherine plays with their insecurities, targeting their weak points. In this sense, Catherine can be considered a modern Medusa, who has been given by Athena a threatening gaze after being raped by Poseidon, which brings about destruction and death. Medusa, though she lost her beauty and youth, is no longer a victim of male brutality but turned into a vengeful victimizer and gains the status of an invincible enemy to all mighty male heroes. Cathy has inherited her eyes from her mother, which disturb Heathcliff and Lockwood.

Catherine refuses to eat for three days, which causes delirium and hallucinations, leaving her fatigued and "listless" (114), with bloodless cheeks. Catherine`s mental instability and hysteria and her following withdrawal into silence and self-starvation, which brings her own self-destruction can be taken not as the expression of helplessness but as an act of self-defense and resistance against the tyranny: "I'm in danger of being seriously ill — I wish it may prove true [...]. If I cannot keep Heathcliff for my friend - if Edgar will be mean and jealous - I'll try to break their hearts by breaking my own" (90-91).

Levy takes Catherine`s death as the "suicide of adulthood", that is "her refusal to identify with adulthood" since she has never been able to overcome "the loss of innocence" (Levy 165). However, by and in death, Catherine triumphs. As Laura Inman maintains, "death is in large part a return to and a unity with nature: the outdoors, the earth and the moors" (194). She desperately covets to go to the moors one more time before she passes away: "I shall never be there, but once more [. . . ] and then you'll leave me, and I shall remain, forever" (104). Bloom states that the realm of the moors and the surroundings in the novel is "what the ancient Gnostics called the kenoma, a cosmological emptiness into which we have been thrown" (24). Pagels also describes kenoma as the "emptiness" or "void" (qtd. in Dodworth 129). Consistent with those above, Dodworth sees the moors as "kenoma, or more hellish purgatory" and the land of the Other, "an entity that tends toward the qualification of evil" (133). Purgatory in a religious context refers to a temporary space where the soul can be purified and purged away before gaining access into a heaven. However, to Catherine, it is the heaven itself. The incarceration of the room and her own life become so suffocating that she asks for a window to be opened several times at the Grange: "Oh I am burning! I wish I were out of doors. I wish I were a girl again, half-savage and hardy, and free [...] I'm sure I should be myself were I once among the heather on those hills [...] Open the window again wide, fasten it open!" (126). Catherine, during her second brain fever, which has worsened her situation, tells Edgar: "Suppose we shall have plenty of lamentations, now [...] but they can't keep me from my narrow home out yonder My resting place where I'm bound before Spring is over!" (97). The "perfect peace" Nelly sees on the face of dead Catherine is a clear indication of this long-delayed union between Catherine and the Moors.

Heathcliff"s quenchless desire for Catherine is so unbearable that Catherine's death brings to him extreme misery and desperation: "it is unutterably too much for flesh and blood to bear, even mine". He hits his head against the tree out of helplessness because he feels defeated to Edgar. Catherine died as his wife, his belonging. Heathcliff's extended obsession with her ghost grows out of his failure to make her his thing. His unearthing of Catherine's corpse on the night she was buried is the amplification of his pathological wish to push Edgar aside to possess her body alone, which will eventually compensate for his failure because the dead Catherine will belong to him forever. His eroticization of the corpse can be associated with necrophilia. In complete self-deception and self-delusion, he idealizes his relationship with Catherine after death. Obviously, Heathcliff needs Catherine to mollify his hurt and damaged self-image by success and achievement that are to be experienced through an intercourse with her dead body. 
It is common misinterpretation that Catherine's ghost seeks reunion with Heathcliff. According to Piciucco, $W H$ suggests the re-union of the indissoluble lovers (225). However, even while she was alive, she knew very well that this union was unlikely. It is ironical that her ghost never appears to Heathcliff but to a foreigner, Lockwood to ask to be let in although Heathcliff desperately waits for her coming: "Come in! Come in! Cathy, do come. Oh do - once more! Oh! my heart's darling, hear me this time - Catherine, at last!" (23). Catherine, who transcends the socio-cultural impositions when alive, now transcends the death and her non-present existence still dominates not only WH and TG but also the moors. She seeks access to her home which is denied to and usurped from her. Catherine now has an access to the moors but refuses to come in as long as Heathcliff controls the domestic household and the interiority of the house. She is aware of the fact that not only Heathcliff but the other male dweller of Wuthering Heights, Joseph, will never make her feel at home again. Catherine`s restlessness after death stems from her failure to take her home back from Heathcliff and her remark "let me in, let me in" is a reaction against this exclusion.

Edgar is buried on one side and Heathcliff on the other side of Catherine, leaving her in between. This should not be interpreted as the eventual union of the lovers in death but as an attempt for the extension of the imprisonment and domination of Catherine. Even their deaths fail to bring closure to this never-ending fight and after her death, the struggle for possession even reaches to the extremity of necrophilia. This time they fight for the dead body. Catherine has a locket in which Heathcliff's hair is put together with Edgar's (205). Heathcliff's fixation on Catherine leads him to unearth her corpse, which is for sure a seduction. It was the day of her burial when Heathcliff, for the first time, digs up her grave to take her in his arms again. Eighteen years later when Edgar is buried, he makes some arrangements like opening her coffin-lid and loosening one side of the coffin and he bribes the sexton to do the same to his coffin after his death so that their bodies could mix together in death eternally and "By the time Linton gets to us, he'll not know which is which!" (218-219).

Heathcliff"s death in Catherine's old panelled bed with the window open and his hand wet on the window sill in the rain is ironical. Catherine manages to confine him where once she was confined and through the open window she gets access to Wuthering Heights in the form of rain. Thunderstorms and rain purify and cleanse away all the sins and wrong done against women and the devil inflicted by male domination. The window in Catherine's room gains a symbolic meaning. Her daughter Cathy also escapes just in time from her mother's bedroom window to see her father for the last time before he dies. Thus, the window functions as a gate opening into freedom.

It was the tradition for the members of Thrushcross Grange to be buried not in the churchyard like the rest of the community but under a carved monument within the church itself. Catherine is unconventionally buried against the family traditions in the corner of the churchyard, overlooking the moors. Lockwood notices that the moorland plants have begun to creep down into the churchyard. Catherine's peaceful existence in her permanent dwelling place is disturbed when Edgar and Heathcliff persist in joining Catherine in death. This seems defeat for Catherine. However, as in the case of kitchen, Catherine pulls them closer to a female nature where she is more likely to gain victory by disconnecting them from their patriarchal culture. To do so, Catherine makes a call for Heathcliff: "Will you venture...they may bury me twelve feet deep...but I won`t rest till you are with me" (98). Thus it is not Heathcliff who keeps her in confinement but it is Catherine who beguiles him. Thus both Heathcliff and Edgar are tricked into ending up in the moors by the challenge she exposes with courage.

\section{Conclusion}

There have been many different comments on the nature of love and connection between Heathcliff and Catherine. This paper has discussed that $W H$ is neither about different forms of love nor limitations of love nor destructive and corrupting influence of love nor the passion of love. What is at the heart of the novel is the resistance displayed not only by Catherine and Cathy but also by Isabelle against the docilizing and regulating social and cultural systems of capitalist patriarchy. Heathcliff, Hindley and Edgar feel no genuine love, compassion or tenderness neither for Catherine nor Isabelle. The female characters are reduced to a battlefield where Edgar and Heathcliff launch a war against each other for power and ownership. Heathcliff directs cruelty to everybody close to Catherine since they are seen as an obstacle standing in his way to possess her alone. WH shows the impossibility of the coexistence of love and unquenchable desire for possession and domination. Compassion, affection, care, sympathy on one side and victimization, subordination and oppression on the other side are irreconcilable. What endure and triumph are the windy moors in the Yorkshire village of Haworth where Bronte lived and which gave her the inspiration for her novel. The moors has become a literary shrine where Catherine`s soul wanders around.

\section{References}

Baldys, Emily M. "Earnshaw and the Shadow of Idiocy: Disability and Domestic Disorder in Wuthering Heights." Philological Quarterly, vol.91, no.1, 2012, pp. 49-74.

Beaumont, Matthew. "Heathcliff's Great Hunger: The Cannibal Other in Wuthering Heights." Journal of Victorian Culture, 9, 2004, pp. 137-163.

Berry, Laura C. "Acts of Custody and Incarceration in Wuthering Heights and The Tenant of Wildfell Hall." NOVEL: A Forum on Fiction, vol.30, no.1, 1996, pp. 32-55.

Bloom, Harold. The Victorian Novel. Chelsea House Publishing, 2004.

Bronte, Emily. Wuthering Heights. W.W. Norton \& Company, Inc, 1990. 
Buell, Lawrence. The Environmental Imagination: Thoreau, Nature Writing, and the Formation of American Culture. Princeton University Pres, 1995.

Clark, Timothy. The Cambridge Introduction to Literature and the Environment. Cambridge University Press, 2011.

Cory, Abbie L. "Out of My Brother's Power: Gender, Class and Rebellion in Wuthering Heights.” Women's Studies, 34, 2004, pp. 1-26.

Crouse, Jamie S. "This Shattered Prison: Confinement, Control and Gender in Wuthering Heights." Brontë Studies, 33, 2008, pp. 179-191.

Dodworth, Cameron. "The Mystery of the Moors: Purgatory and the Absence/Presence of Evil in Wuthering Heights." Bronte Studies, vol.37, no.2, 2012, pp. 125-135.

Davies, Stevie. "Baby-Work: The Myth of Rebirth in Wuthering Heights' in Emily Bronte's Wuthering Heights." Macmillan Casebook Series, edited by Miriam Allot. London: 1970.

Eagleton, Terry. Heathcliff and the Great Hunger: Studies in Irish Culture. Verso, 1995.

Gilbert, Sandra and Susan Gubar. The Madwoman in The Attic. Yale University Press, 1984.

Heywood, Christopher. "Yorkshire Landscapes in Wuthering Heights." Essays in Criticism, vol.48, no.1, 1998, pp. 1334.

Homans, Margaret. "Repression and Sublimation of Nature in Wuthering Heights" Modern Language Association, vol.93, no.1, 1978, pp. 9-1.

Inman, Laura. “'The Awful Event’ in Wuthering Heights.” Bronte Studies, vol.33, no.3, 2008, pp. $192-202$.

Kennard, Jean E. "Lesbianism and the Censoring of Wuthering Heights." NWSA Journal, vol.8, no.2, 1996, pp. 17-36.

Kolodny, Anne. "Unearthing Her Story." The Ecocriticism Reader: Landmarks in Literary Ecology, edited by C. Glotfelty and H. Fromm. Univerity of Georgia Pres, 1996, pp. 170-181

Levine, George. "High and Low: Ruskin and Novelists." Nature and The Victorian Imagination, edited by U.C. Knepflmacher and G.B Tennyson. University of California Press, 1977, pp. 137-152.

Levy, Eric P. “The Psychology of Loneliness in Wuthering Heights.” Studies in the Novel, vol.28, no.2, 1996, pp. 158177.

Lewis, C.S. Abolition of Man. Oxford University Press, 1944.

Lutwack, Leonard. The Role of Place in Literature. Syracuse University Press, 1984.

May, Rebecca E. "This Shattered Prison: Bodily Dissolution, Wuthering Heights, and Joseph Maclise's Dissection Manuals." Nineteenth-Century Contexts, vol.33, no.5, 2011, pp. 415-436.

Matthews, Bronte. "The spelling of the name." Bronte Society Association, vol.23, no.2, 1998, pp. 177-189.

Merchant, Carolyn. The Death of Nature: Women, Ecology and the Scientific Revolution. Harper Collins Publishing, 1980.

Mies, Maria and Shiva, Vandana. Ecofeminism. Fernwood Publications, 1993.

Morton, Timothy. The Ecological Thought. Harward University Press. 2010.

Norwood, Vera. L. "Heroines of Nature: Four Women Respond to the American Landscape." The Ecocriticism Reader: Landmarks in Literary Ecology, edited by C. Glotfelty and H. Fromm, Univerity of Georgia Pres, 1996, pp. 323-350.

Ohmann, Carol. "Emily Bronte in the Hands of Male Critics." National Council of Teachers of English, vol.32, no.8, 1971, pp. 906-913.

Paris, Bernard J. “'Hush, hush! He's a Human Being': A Psychological Approach to Heathcliff.” Women in Literature, vol.2, 1981, pp. 101-17.

Plumwood, Val. Feminism and the Mastery of Nature. Routledge, 1993.

Przybylowicz, Samantha. "(Dys)Function in the Moors: Everyone's a Villain in Wuthering Heights." Iowa Journal of Cultural Studies, 14, 2013, pp. 6-20.

Phillips, James. "The Two Faces of Love in Wuthering Heights" Bronte Studies, vol.32, 2007, pp. 96-107.

Piciucco, Pier Paolo. “Wuthering Heights As a Childlike Fairy Tale.” Bronte Studies, vol. 31, 2006, pp. $220-231$.

Relph, Edward. Rational Landscapes and Humanistic Geography. Barnes and Noble Books, 1981.

Russ, Joanna. How to Suppress Women's Writing. USA: University of Texas Press, 1983.

Senf, Carol A. "Emily Brontë’s Version of Feminist History: Wuthering Heights." Essays in Literature, vol.12, 1985, pp. 201-14.

Showalter, Elaine. A Literature of Their Own. Princeton University Press, 1977.

Stoneman, Patsy. "Catherine Earnshaw's Journey to Her Home among the Dead: Fresh Thoughts on Wuthering Heights and 'Epipsychidion'” The Review of English Studies, vol.47, no.188, 1996, pp. 521-533. 
Thompson, Nicola. "The Unveiling of Ellis Bell: Gender and the Reception of Wuthering Heights." Women's Studies: An Inter-disciplinary Journal, vol.24, no.4, 1995, pp. 341-367.

Thormahlen, Marianne. "The Lunatic and the Devil's Disciple: The 'Lovers' in Wuthering Heights.” RES New Series, vol. XLVIII, no.190, 1997, pp. 185-201.

Tytler, Graeme. “'Nelly, I Am Heathcliff!': The Problem of 'Identification' in Wuthering Heights.” The Midwest Quarterly: A Journal of Contemporary Thought, vol.47, no.2, 2006, pp.167-81.

Williams, Anne. "Natural Supernaturalism in Wuthering Heights." Studies in Philology, vol.82, no.1, 1985, pp. 104127. 